\title{
Accounting
}

\section{Corporate social responsibility, employee commitment, reputation, government support and financial performance in Vietnam's export textile enterprises}

\author{
Trong Lam Vu ${ }^{a}$, Ngoc Toan Nguyen ${ }^{b}$, Xuan Hung Nguyen ${ }^{c^{*}}$, Quang Huy Nguyen ${ }^{c}$ and Hong Linh \\ Nguyen ${ }^{d}$
}

${ }^{a}$ Communist Review, Vietnam

${ }^{b}$ University of Economics, Technology for Industries, Vietnam

${ }^{c}$ School of Trade and Internaional Economics, National Economics University, Vietnam

${ }^{d}$ International economic 59A-Excellent Educational Program, National Economics University, Vietnam

\begin{tabular}{l}
\hline C H R O N I C L E \\
\hline Article history: \\
Received May 152020 \\
Received in revised format May \\
162020 \\
Accepted July 62020 \\
Available online \\
July 152020 \\
\hline Keywords: \\
Corporate social responsibility \\
Employee commitment \\
Government support \\
Corporate reputation \\
Financial performance \\
Textile \\
Vietnam
\end{tabular}

\section{A B S T R A C T}

\begin{abstract}
The objective of this paper is to assess the impact of corporate social responsibility (CSR) on the financial performance of textile and garment export enterprises in Vietnam. We conducted an analysis on 396 textile and garment enterprises exporting in Vietnam and the results show that CSR had a positive impact on financial performance through a positive impact on corporate reputation, a positive impact on employee commitment and positive impact on government support. Since then, corporate reputation, employee commitment and government support also had a strong positive impact on the financial performance of these export textile enterprises. Finally, based on the results of testing the research hypotheses, we propose solutions for Vietnam textile enterprises in general, export textile enterprises in particular and recommend solutions for Government to support businesses to implement CSR more effectively, ensuring sustainable development for the economy.
\end{abstract}

C 2020 by the authors; licensee Growing Science, Canada

\section{Introduction}

Currently, issues of accelerating economic growth are always concerned, besides it is always about environmental, social and community issues. For this reason, policies on social responsibility are formed. Leading the way is the developed countries, the social responsibility activities are widespread in developing countries and Vietnam is no exception, especially in the trend of integration and fierce competition. like nowadays. Businesses play a role in connecting economic actors and pioneering the implementation of global trends such as corporate social responsibility (CSR). Globalization and information sharing are easy. The global responsibility of social responsibility has become a leading issue in the strategic plan of organizations of all types, including profit and non-profit organizations. As the level of competition is increasingly fierce, the requirements meet the increasing demands of importing countries, along with that, society has an increasingly stricter view towards businesses on their duties and responsibilities to the community. In society, businesses want to develop sustainably must always follow the standards and the best things to be able to meet the requirements set by society as well as importing countries.

* Corresponding author. Tel.: +84 903201642

E-mail address: hungnx@neu.edu.vn (X.H. Nguyen) 
The fact shows that CSR implementation of enterprises is increasingly appreciated and identified as an important factor leading to sustainable development, especially in the integration period as at present. It has become familiar and indispensable in the annual reports of enterprises. For companies in Vietnam, a lot of policies and programs aimed at people, society and community are launched. Taking Vinamilk as a typical example, this Vietnamese dairy company always fulfills its commitments on product, environment, capacity and social issues. Among the 10 most worthy companies in Vietnam, it can be said that after nearly 50 years of development, Vinamilk still maintains its value, which is an undeniable achievement of CSR for businesses.

International economic integration is the current global trend and also the goal that Vietnam is aiming at, it can be said that the textile industry in recent years has always been one of the leading export industries. of Vietnam, along with the strong development of technical technology and skilled workers, along with the preferential policies of the textile industry so far can create export values, while ensuring domestic demand. In addition, according to the 2015 Global CSR study, $91 \%$ of global consumers expect businesses to operate responsibly to address social and environmental issues. Moreover $84 \%$ said that they seek products from ethically operating businesses. Therefore, improving CSR not only helps businesses gain prestige and competitive advantage in foreign markets, but also increases revenue and ability to raise capital for businesses. Therefore, corporate responsibility has become one of the requirements for Vietnamese enterprises in general and export textile enterprises in particular.

The objective of this paper is to assess the impact of CSR on all 6 aspects of employees, the environment, customers, suppliers, investors, the community on employee commitment, the reputation of the business, the government support and ultimately financial efficiency. The structure of the paper in addition to the introduction includes: Overview of research, research methods, research results and conclusions.

\section{Literature review}

\subsection{Corporate social responsibility}

Since the 1960s, the concept of corporate social responsibility has not been unanimous, each with its own meaning and approach. CSR has been defined in various ways since the time of conceptualization. Carroll (1979) developed the famous "pyramid" model that clearly describes the concept of CSR corresponding to four regions: Economics, law, ethics and charity. These concepts come from a very narrow economic point of view that CSR is about maximizing profits for shareholders (Zenisek, 1979). However, there are also scholars who look at this issue more broadly and broadly. Jones (1980) also recognizes that corporate social responsibility means that companies have an obligation to the constituent groups of society (other than shareholders) and more, in accordance with the law. Besides, Brown and Dacin (1997) also said that CSR includes the activities of companies respecting the obligations of businesses to society or at least obligations to related parties.

In the period from 2000 to the present, the concepts of CSR were also introduced by many famous scholars such as Holme and Watts (2000) with the view that CSR is continuing the enterprise's commitment to behave ethically and it contributes to economic development while improving the quality of life of the workforce as well as society and the community. It can be said that this statement is not new but is supplemented with a definition. In addition, social responsibility is defined when those activities are implemented by an organization to improve some social goals beyond the interests of the company and the requirement of the law is also a new definition (McWilliams \& Siegel, 2001). Carroll (2015) again provided an article on how to better understand this issue. Corporate social responsibility encompasses society's expectations of economy, law, ethics and philanthropy that a business needs to meet at a given time (Nikolova \& Arsić, 2017). The social responsibility of a company includes economic, ethical and humane entities (Davis \& Searcy, 2010). According to Wood (1991), CSR has so far been expanded to all three levels of responsibility: institutional and economy-wide, business and organizational, and personal.

\subsection{Aspects of CSR}

Most of the initial definitions of CSR focus on what constitutes corporate social responsibility and why businesses should be socially responsible (Firth, 1979). Carroll (1979) argues that CSR is a combination of economic, legal, ethical and social expectations for businesses. Moreover, Clarkson (1995) defined a group of stakeholders as a group of people influenced or influenced by a corporation. For each stakeholder, there should be a relationship between companies and stakeholder groups (Roberts, 1992). Accordingly, shaping the CSR for each stakeholder group is synonymous with the organization's policies, processes and practices for stakeholder groups. Stakeholders' interests thus form the basis of all goals pursued by management such as growth and investment in social initiatives. Thus, in order to have the most general assessment of CSR, businesses should identify CSR from the theoretical perspective of stakeholders. Friedman and Miles (2002) divided stakeholders into internal and external. Stakeholders within the business are those whose actions are of primary importance to the company's business operations, while the external are stakeholders capable of influencing perceptions and attitudes. internal stakeholders. In addition to the foregoing, internal stakeholders have power and allow them to influence the management of businesses, while outside stakeholders do not have direct management access. 
Sustainable and socially responsible business create a range of benefits for not only the community and the environment, but also for the company's business activities (Davis \& Searcy, 2010). Businesses, which are considered socially responsible, have the ability to create a positive reputation and create a competitive advantage. In addition, conducting, as well as fully and transparently communicating social responsibility activities, will positively affect consumer satisfaction and confidence, allowing them to identify values. and corporate awareness to society. Partial or complete compliance with an enterprise's CSR may also result in consumers' willingness to pay higher prices for products and services, thus creating direct financial benefits for the company. For suppliers, awareness of the importance of corporate social responsibility issues with suppliers in recent years has been raised. According to Phan and Nguyen (2019), this means: ensuring procurement of materials and ethical transactions with suppliers, eliminating child labor / human rights violations at suppliers. For consumers, according to Mishra and Suar (2010), CSR with consumers is expressed in providing products that meet consumer needs, quality of standard products, reasonable prices, honesty. in product promotion, and safe for users. It is easy to see that once a product satisfies the needs of consumers, the image of the product and brand of the business will leave a good impression on the consumer. For the community, a previous study showed that businesses and communities have a close relationship, interacting with each other. According to ISO 26000, corporate social responsibility with the community is expressed in decisions and activities for society through transparent and ethical behavior. This is also an expression of business ethics, showing a positive contribution of material and spiritual values to the social community. In addition, there has been a dramatic increase in media and nongovernmental organizations' discovery of socially irresponsible business activities in recent years, making social responsibility a reality. Business associations are increasingly becoming a positive means to compete in the industry. As the media reported on socially irresponsible business activities, the number of outside stakeholders was also skeptical of the company's products (Skarmeas \& Leonidou, 2013). Improving CSR with the community is addressing issues such as charity, public-private partnerships, social and economic development of the community. For investors, Gillis and Spring (2001) studied and concluded that investors prefer to cooperate with socially responsible businesses. Currently, in the process of integration and globalization, the decisive factor affecting the investment attraction of enterprises is the compliance with corporate social responsibility commitments.

With regard to the natural environment, climate change or global environment has been paid special attention. Hasan et al. (2018) emphasize the importance of environmental sensitivity and production performance by companies. International standards such as ISO 14000, EMAS and OHSAS 18000 together with environmental laws in different countries have been developed. Following CSR standards with the environment means that businesses are developing in a sustainable way: commitment to protecting the environment, ensuring that the operation of the business does not cause harm to the ecological environment. must be environmentally friendly in the course of production and business activities. Corporate social responsibility for the environment is of particular importance to any business. The implementation of social responsibility will help businesses have a safe working environment, bring health benefits to employees and ensure labor productivity. In addition, the full compliance with environmental laws will help businesses not to face legal risks, inspection and sanctions. The important thing is that when doing well the environmental protection, businesses also improve business results. So, the interaction between the results of social responsibility will help businesses develop stably. Countries around the world often commit to comply with the common rules of corporate social responsibility, including a number of them: BSCI (reflecting international labor standards), SA 8000 (improve working conditions of workers), ISO 26000, EICC (social responsibility in the global electronic supply chain), WRAP (standards and conduct for manufacturing enterprises, apply more for garment businesses). Although the concept of corporate social responsibility is primarily directed to outside stakeholders, internal stakeholders also play an important role in business activities. The effectiveness of conducting socially responsible activities equally depends on external and internal stakeholders. For employees, employees, CSR with employees means "good relations with workers". In addition to the positive impact on profits and economic growth, it has been shown that the concept of corporate social responsibility positively affects employee satisfaction, motivation and loyalty. It also allows management to extract the best qualities from each employee, directly contributing to the creation of positive business trends. Ali et al. (2010) came to a similar conclusion, saying that a higher level of social responsibility positively affects employee loyalty, which significantly improves the efficiency of business processes. A higher level of motivation, loyalty and satisfaction due to socially responsible business practices allows employees and other internal stakeholders to identify organizational values.

For managers, owners, this is the object that greatly affects the CSR of the business. For managers and owners who are aware of the need for CSR as well as understand the benefits that CSR brings, the CSR issue is always appreciated by that business and implemented according to the development guideline. In order for management to benefit through social responsibility, socially responsible activities must be fully communicated to internal and external stakeholders through various communication channels. Corporate social responsibility reporting, websites, social networks and advertising all represent the main communication channels of today's social responsibility (Smith et al., 2001). At this point, managers and owners act as two-way and direct communicators with internal and external stakeholders to integrate websites and social media into the communication strategy. corporate social responsibility. Although investing in socially responsible activities often requires the initial investment of financial resources, the company is able, by properly communicating with stakeholders, to achieve financial returns. 
investment and thus increase the value of long-term monopoly benefits (Smith et al., 2001). Therefore, it can be pointed out that the concept of corporate social responsibility has reached the stage of an important business model in the 21 st century.

\subsection{Impact of CSR on financial performance}

Chetty et al. (2015) studied the impact of CSR on corporate financial performance. This relationship has been investigated from 2004 to 2013 in South Africa. The author assesses the short-term impact of CSRs on the financial returns of businesses that are included or excluded from the socially responsible investment index of the Johannes-burg Stock Exchange. This will determine whether there is a difference in the long-term financial performance between the two groups. Research methods using regression analysis show that different industries provide mixed results between CSR and financial performance for companies in the long run. Based on these results, the study confirms that CSR activities result in no significant change in financial activity. The study of Agyemang and Ansong (2017) aims to examine the impact of corporate social responsibility (CSR) on the financial performance of small and medium-sized enterprises (SMEs) in Ghana using the Stakeholder participation as an intermediary variable. The main data was collected from 423 small and medium enterprises in Accra Urban Area. CSR is measured by 12 indicators, financial efficiency is measured by revenue growth, profitability and financial leverage growth rate and the intermediate variable is access to capital and reputation. Potential variables in the research model are measured by 5 point Likert scale. The study uses stakeholder theory, legal theory and institutional theory. The authors used PLS - SEM (Smart PLS) analysis techniques to conduct EFA, CFA analysis and hypothesis testing. Bootstrap technique is used. The study has documented evidence for a mechanism through which CSR leads to financial performance of businesses: Small and medium-sized enterprises that improve CSR have a better chance of reaching out to stakeholders help improve financial efficiency. Research has encouraged small and medium-sized enterprises to improve their CSR activities, which will lead to improved financial performance and stakeholder engagement should be a major part of the activity. The research results also show that capital access has an intermediary role leading to a negative relationship between CSR and financial performance.

\subsection{The relationship between CSR and financial performance through mediate factors}

Obeidat (2016) aims to explore the relationship between corporate social responsibility, employee engagement and organizational performance in Jordan's mobile telecommunications businesses. A total of 350 questions contain 37 items used to collect information. Simple and multiple regression analysis is performed to test the research hypotheses. The results of the current study show that corporate social responsibility and employee engagement are significantly positively associated with firm performance. In addition, the results show that there is a significant positive relationship between corporate social responsibility and employee engagement. The Baron and Kenny mediation model and the Sobel test were used to check whether employee engagement was mediated between the corporate social responsibility relationship and the firm's performance. The results show that employee engagement completely reconciles the relationship in a meaningful way. The results of the current study have significant management implications for mobile telecommunications companies. Therefore, to enhance the performance of the business, decision-makers must implement and maintain social responsibility effectively, which will increase the cohesion of employees in the work of them, resulting in improved performance.

Brik et al. (2010) performed a survey on market trends, corporate social responsibility and business performance. The study examines the impact of corporate social responsibility (CSR) on the relationship between market trends and firm's business performance in the context of an emerging economy. The sampling framework consists of 2,200 Dubai businesses taken from the member database of the Dubai Chamber of Commerce and Industry (DCCI) and in the form of a questionnaire by email or fax to a senior manager in every business. The response rate is $14 \%$ (310 firms). A total of 280 businesses were still in the sample after eliminating those that missed market trends, CSR and business performance. Results from a sample of businesses operating in Dubai show that CSR has an overall impact on market trends on business performance. Research on the impact of CSR on sets of market trends shows that although there is an effect of CSR on the relationship between customer orientation and business performance, it does not regulate the relationship. The combination of competition, coordination and interfunctional performance.

\subsection{Financial performance}

The nature of an enterprise's performance is to reflect its ability to use its resources (human, financial, material and capital) to achieve socio-economic goals. Performance must be expressed on both spatial, temporal and qualitative and quantitative terms. For example, in terms of time, operational efficiency reflected in each period, each stage and business cycle of an enterprise. Enterprises operate effectively when the following periods and business cycles are more efficient or do not decrease in effectiveness compared to the previous periods, periods and business cycles. That requires businesses to work towards sustainable development, not for immediate benefits but for long-term benefits. In business practice, this is likely to happen when many Vietnamese businesses have acted contrary to sustainable development, infringing on the interests of stakeholders such as pinching workers, selling goods, counterfeit goods, poor quality goods, tax evasion, appropriation of illegal capital of suppliers, causing environmental pollution. The performance of an enterprise is considered to be comprehensively achieved 
only if the performance of the activities in the business functions does not affect the overall efficiency, minimizing the business costs. by exploiting the resources available to achieve the best results for the business. There are many criteria to evaluate the performance of a business. The selection of evaluation criteria is a key factor for the success of the business. Therefore, the criteria for measuring the performance of enterprises are often divided into different groups, especially the financial indicators are the most common and often used in studies to assess the economic efficiency of enterprises. enterprise. Return on assets (ROA) is an accounting-based measurement to evaluate the performance and financial performance of a company (Santos \& Brito, 2012, Tran et al., 2019; Le et al. 2019; Phan et al. 2019). The higher the ROA, the more effective it is to use assets to give advantages to shareholders. Moreover, a higher ROA reflects a company's efficient use of its assets in the economic interests of its shareholders. Debt and equity of the business is the source of the assets of a business, and is also used to finance the operations of the business. A higher ROA also indicates that businesses are making a lot of profit from total assets. Return on equities (ROE) is often used to compare a company with competitors and the common market, especially when comparing companies in the same industry. For example, in the third quarter of 2019, Bank of America Corporation's (BAC) quarterly earnings report had a ROE of $8.48 \%$. According to the quarterly report of the Federal Deposit Insurance Corporation (FDIC), the average ROE of the banking industry in the same period was $11.67 \%$. In other words, Bank of America is underperforming in the industry.

ROE can also be calculated at different stages to compare its change in value over time. For example, by comparing the growth rate of ROE from year to year or quarter to quarter, investors can track changes in management's activities. The Tobin's Q coefficient is considered a traditional measure of the future performance of enterprises (Santos \& Brito, 2012). Using the market value of equity can provide an opportunity for the firm's future growth that may stem from exogenous factors for management decisions and this is indicated by firm level (Santos \& Brito, 2012). Furthermore, market-based assessments of firm performance can lead to incentives for revision management based on their expectations of future business performance (Santos \& Brito, 2012). As a result, when the firm's market-based performance is higher than that of Tobin's Q, this indicates that the firm has succeeded in achieving its planned high performance (Santos \& Brito, 2012) but if it's lower than Tobin's Q, then businesses need to revise their plans to increase short-term efficiency. Negative performance results in loss of investors (domestic and foreign) and therefore, it is important for enterprises to update their targets over time if they want to compete in the market.

\section{Research method}

\subsection{Study sample and research context}

Textile and garment industry is known for a long time together with a rich history of development, until now, the textile industry has always been one of the leading and influential industries to the life of Vietnamese people. Experiencing the history of formation and development with many changes, up to now, the textile industry is holding an important position in Vietnam's economy in terms of growth rate and the ability to expand its export. According to the Vietnam Textile and Apparel Association (Vitas) report on the performance of the export textile industry, by the end of 2019, the total export turnover of this sector reached US \$ 39 billion, down US \$ 1 billion compared to the targets, instead of the trade surplus reached the highest ever increase with 17.7 billion USD. Compared to 1999, it has increased by 22 times, from 17.5 billion USD to 39 billion USD. The trade surplus in 2019 reached US \$ 17.7 billion in 2019, greatly contributing to the country's export turnover in 2019 surpassing the US \$ 500 billion mark. The size of the labor force in the textile and apparel industry is very large. The industry has created about 2.2 million jobs every year. However, in reality, the labor is mainly unskilled labor. The level of awareness and understanding of international laws and standards is limited. After the research team distributed 500 survey questionnaires to enterprises operating in Vietnam's textile and garment industry and collected 452 questionnaires. The research team eliminated the questionnaires that were too vacant and inappropriate, the remaining 396 valid questionnaires were included in the final analysis.

\subsection{Research models}

- Corporate Social Responsibility (CSR): implement corporate social responsibility with the aim of building relationships with better stakeholders such as customers, suppliers, employees, community, investors and environment (Rettab et al., 2009; Phan, 2019).

- Employee commitment: Employee's commitment to stick and work for a long time with the business. This commitment is also reflected in the reduction in employee turnover; the trust and satisfaction of employees with the business. The scales were developed from research by Rettab et al. (2009)

- Reputation of the business (CR): The image of the business in the heart of customers and employees about product quality, working style, ability of sustainable development (Tran et al., 2019; Saeidi et al., 2015; Henseler et al., 2009, 2015).

- Government support (GS): the government creates favorable conditions for businesses to develop through various contents such as supporting administrative procedures, creating tax and customs incentives, and helping recruiting more labor, subsidies for businesses and the scales are developed from the research of Phan (2019). 
- Financial efficiency (FP): The effect of raising and using capital of enterprises and is usually measured through three aspects: profitability; growth and market value. The scales were developed from research by Rettab et al. (2009), Phan (2019) and Phan et al. (2019).

All scales are measured by a 5-point Likert scale with 1 being strongly disagree and 5 being strongly agree. The scales for the latent variables are detailed in the appendix.

The research hypotheses of the research model are as follows:

$\mathrm{H}_{1}$ : CSR has a positive impact on the reputation of export textile enterprises in Vietnam.

$\mathrm{H}_{2}$ : CSR has a positive impact on employee commitment in export textile enterprises in Vietnam.

$\mathrm{H}_{3}$ : CSR has a positive impact on government support to textile and apparel exporters in Vietnam.

$\mathrm{H}_{4}$ : Reputation of Vietnamese textile and garment export enterprises has a positive impact on their financial performance.

$\mathrm{H}_{5}$ : Commitments of employees in Vietnam's export textile enterprises have a positive impact on their financial performance.

$\mathrm{H}_{6}$ : Government support for Vietnamese textile and apparel export enterprises has a positive impact on their financial performance.

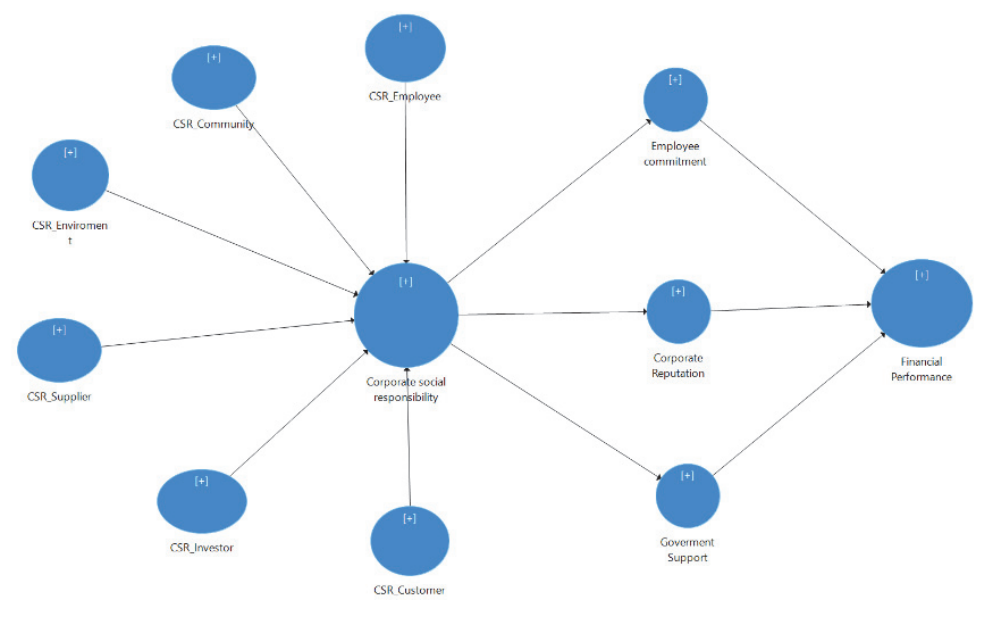

Fig. 1. Research model

\subsection{Analytical techniques}

To test the research hypotheses, we conducted research data analysis on two basic data analysis software, SPSS 22 and Smart PLS 3.6. and performed the reliability test, the value of the scale. We then analyze the discovery factor (EFA) of the variables through factor loading and finally evaluate the research model and test the research hypotheses. Assessing reliability of scales: the commonly used reliability is the internal consistency of the scale reflecting the relationship of observed variables in the same scale. The reliability of the scale used in this study is Cronbach's coefficient Alpha. The collected data is entered into the computer via SPSS 20.0 statistical software. After coding and cleaning the data, conducting the reliability assessment of the scale through Cronbach's Alpha coefficient with Cronbach's Alpha coefficient of 0.6 or higher is acceptable Hair et al. (2011); Hesenler et al. (2009; 2015). Discovery factor analysis (EFA): all observed variables relate to all factors by a factor load factor. The simple structure is achieved when each observed variable has a high load factor for only one factor and has a low load factor for other factors. Factor analysis is only used when KMO coefficients (Kaiser-Meyer-Olkin) are at or above 0.5 (Hair et al., 2013; Hesenler et al., 2009). Variables with a total correlation coefficient less than 0.3 are considered trash and will be removed from the scale (Hair et al., 2014). Eigenvalue stops (representing the variability explained by each factor) are greater than 1 and the total cumulative\% (Cumulative\% Extraction Sums of Squared Loadings) is greater than 50\% (Hesenler et al., 2015). Variables with a single correlation coefficient between variables and factors less than 0.5 are excluded. To achieve discriminant validity, the difference between factor load factors must be greater than or equal to 0.3 (Hersence et al., 2009). The method of extracting "Principal Axis Factoring" with the "Promax" rotation is used in the factor analysis of independent components. The salient feature of EFA is that factors are drawn from statistical results, not from theory. The basic structure of the data determines the factor structure. Thus, EFA is conducted without knowing how many factors and each observing variable will belong to. Factors appearing are only named after the factor analysis. In addition, we rely on the factor loading factor established in the PLS analysis step in Smart PLS 3.6. 
Evaluation of measurement model: Scale reliability: Composite Reliability (CR) is greater than 0.7 . The convergence value: the scale reaches the convergence value when the variance extracted (Average Variance Extracted - AVE) is greater than 0.5 and statistically significant ( $p$-value $<0.05$ ). Differential value: the variance of the highest correlation coefficient (Maximum Shared Variance - MSV) is less than the extracted variance (MSV $<$ AVE); The square root of AVE is greater than the correlation between the two Hensence concepts (2015). Test research hypotheses are examined by Bootstrap technique in Smart PLS software.

\section{Research results}

We first entered data on 396 valid filtered surveys into Excel 2016 software. Next, we conducted coding, naming the study variables. Once we have the input data set, we enter the data into SPSS 22 software to test the reliability of the scales in the potential variables. The testing results show that most of the scales of the variables meet the reliability and validity test conditions according to Hair et al. (2013) and Hesenler et al. (2009) suggestions. This means that most scales have Cronbach's Alpha coefficient>0.7 and the total correlation coefficient $>0.4$. Except for the two scales CSR_Employee 4 and CSR_Supplier 4 with the total correlation coefficient $<0.3$, we excluded the research model. Once these two scales are removed all potential variables satisfy the initial confidence condition. Next, we conducted discovery factor analysis showing KM0 $=0.816>0.5$ at Sig level. $<0.01$ so the data is absolutely good. The latent variables were analyzed into five separate contracts to test the research hypotheses. For data that has been pretested with SPSS 22, we proceeded to import the filtered data via SPSS 22 into Smart PLS 3.6, the results of the general reliability test, the discriminant validity and the fake tests. theory as follows:

Table 1

Construct Reliability and Validity

\begin{tabular}{|c|c|c|c|c|}
\hline & Cronbach's Alpha & rho_A & Composite Reliability & Average Variance Extracted (AVE) \\
\hline CSR_Community & 0.911 & 0.911 & 0.911 & 0.672 \\
\hline CSR_Customer & 0.872 & 0.872 & 0.872 & 0.694 \\
\hline CSR_Employee & 0.910 & 0.911 & 0.910 & 0.629 \\
\hline CSR_Enviroment & 0.872 & 0.872 & 0.872 & 0.695 \\
\hline CSR_Investor & 0.890 & 0.890 & 0.890 & 0.669 \\
\hline CSR_Supplier & 0.898 & 0.898 & 0.898 & 0.638 \\
\hline Corporate Reputation & 0.945 & 0.945 & 0.945 & 0.775 \\
\hline Corporate social responsibility & 0.982 & 0.983 & 0.982 & 0.666 \\
\hline Employee commitment & 0.838 & 0.843 & 0.839 & 0.635 \\
\hline Financial Performance & 0.947 & 0.949 & 0.948 & 0.645 \\
\hline Government Support & 0.920 & 0.920 & 0.920 & 0.697 \\
\hline
\end{tabular}

From the results in Table 1, the Cronbach Alpha coefficients of the research variables are valued at $>0.8$, the smallest value is 0.838 , showing that the research variables have very good reliability. The combined reliability coefficient is large 0.8 and finally the AVE value is greater than 0.6, the smallest value is 0.629 which according to the direction of Hair et al. (2017) and Hesenler et al. (2015) AVE values only need $>0.5$ to satisfy the analysis conditions. Therefore, research data is very good for testing research hypotheses.

Table 2

Discriminant Validity (Fornell-Larcker Criterion)

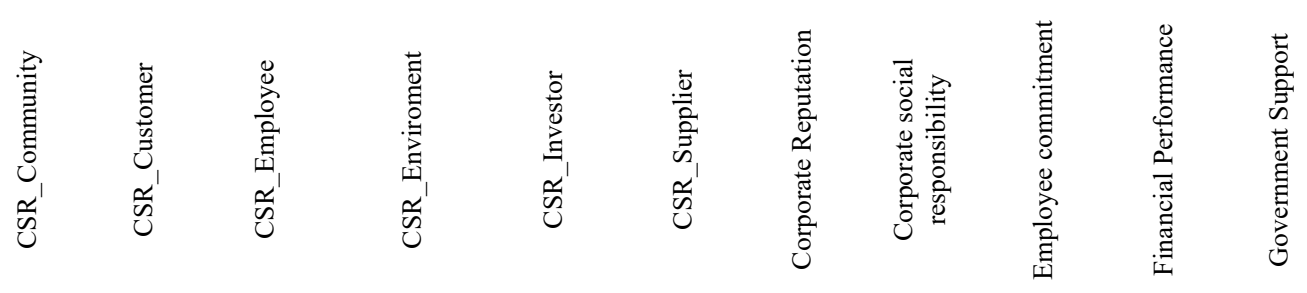

\begin{tabular}{|c|c|c|c|c|c|c|c|c|c|c|c|}
\hline CSR_Community & 0.820 & & & & & & & & & & \\
\hline CSR_Customer & 0.167 & 0.833 & & & & & & & & & \\
\hline CSR_Employee & 0.020 & 0.037 & 0.793 & & & & & & & & \\
\hline CSR_Enviroment & 0.289 & 0.337 & 0.293 & 0.833 & & & & & & & \\
\hline CSR_Investor & 0.191 & 0.197 & 0.039 & 0.236 & 0.818 & & & & & & \\
\hline CSR_Supplier & 0.010 & 0.022 & 0.049 & 0.382 & 0.038 & 0.799 & & & & & \\
\hline Corporate Reputation & 0.164 & 0.169 & 0.172 & 0.155 & 0.194 & 0.193 & 0.880 & & & & \\
\hline Corporate social responsibility & 0.014 & 0.011 & 0.040 & 0.185 & 0.022 & 0.036 & 0.179 & 0.816 & & & \\
\hline Employee commitment & 0.185 & 0.221 & 0.197 & 0.152 & 0.232 & 0.240 & 0.359 & 0.206 & 0.797 & & \\
\hline Financial Performance & 0.330 & 0.315 & 0.326 & 0.313 & 0.338 & 0.367 & 0.381 & 0.333 & 0.339 & 0.803 & \\
\hline Government Support & 0.450 & 0.430 & 0.474 & 0.496 & 0.473 & 0.470 & 0.237 & 0.463 & 0.223 & 0.338 & 0.835 \\
\hline
\end{tabular}


According to Hesenler et al. (2015) to satisfy the discriminant value of Table 2, the values outside the diagonal must be smaller than all the values on the diagonal. In Table 2, the maximum value outside the diagonal is 0.496 , which is still much smaller than the smallest value on the diagonal of 0.797 , so the research variables in the research model satisfy the discriminant value.

Table 3

The results of R-Square

\begin{tabular}{lcc}
\hline & R Square & R Square Adjusted \\
\hline Corporate Reputation & 0.232 & 0.230 \\
Corporate social responsibility & 0.937 & 0.937 \\
Employee commitment & 0.342 & 0.340 \\
Financial Performance & 0.480 & 0.475 \\
Government Support & 0.214 & 0.212 \\
\hline
\end{tabular}

From Table 3, it is clear that the aspects of CSR fully explain the variability of CSR, which means that the concept of CSR has been correctly defined for textile and garment export enterprises in Vietnam, that is a great result. Next, the variables in the model explain nearly $50 \%$ of the variation in financial performance, which is not bad at all. This is indeed a strong research model, consistent with the large research data (Hesenler et al. 2015).

Table 4

The results of Model Fit

\begin{tabular}{lll}
\hline & Saturated Model & Estimated Model \\
\hline SRMR & 0.046 & 0.048 \\
d_ULS & 0.483 & 0.502 \\
d_G & 0.466 & 0.518 \\
Chi-Square & $1,828.506$ & $1,908.123$ \\
NFI & 0.880 & 0.886 \\
\hline
\end{tabular}

From the results in Table 4, the research data is consistent with the research model. All conditions are satisfied to test the research hypotheses. The test results of the research hypotheses are as follows:

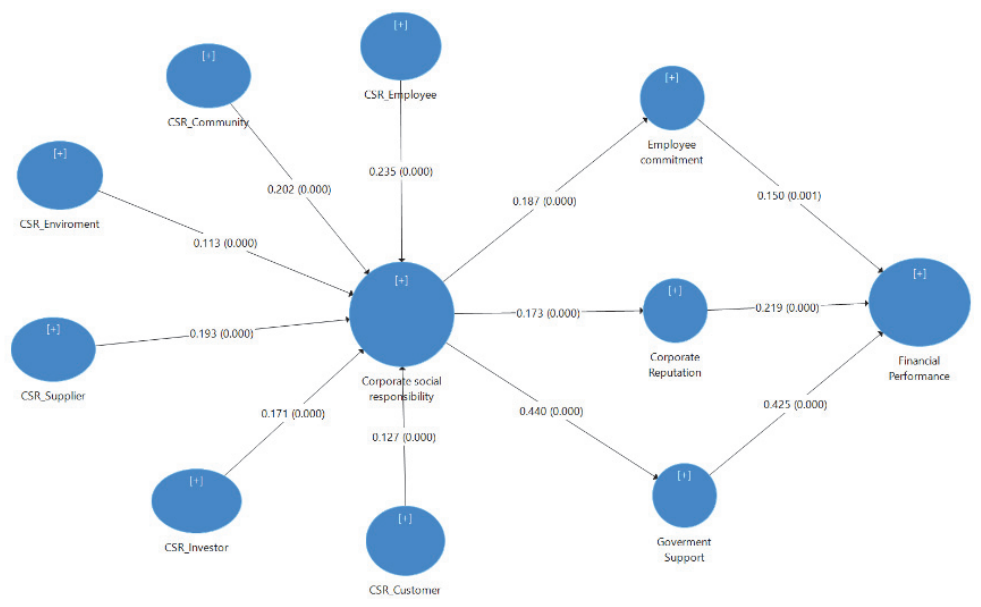

Fig. 2. Test results of research hypotheses

From the testing results in Fig. 2, all six aspects of satisfaction are the constituent elements of corporate social responsibility of Vietnamese textile enterprises. The potential variable of corporate social responsibility is the formative construct which is composed of six aspects: social responsibility to employees, suppliers, customers, investors, the environment and the community. By weighting method in SEM model with Bootstrap technique in Smart PL S 3.6 software, we have determined the overall CSR value to test the research hypotheses. Firstly, CSR has a strong impact on employee commitment, with Vietnamese textile enterprises, corporate social responsibility has a positive impact of 0.187 at $1 \%$ significance level. $\left(\mathrm{P}_{-}\right.$value $\left.=0.000\right)$ this means that the more CSR is done, the more employees are committed to the business. The typical feature of Vietnam's textile and apparel industry is that the products are mainly processed according to orders of famous brands in Europe, America and Japan. With the advantage of cheap labor force, the labor force in Vietnam textile and garment industry is mainly unskilled 
labor. With unskilled workers in particular and all employees in general, CSR activities have a positive effect on employee commitment to the business. Because for businesses with good CSR, the working environment of employees is guaranteed, employees are entitled to benefit in accordance with the labor law sometimes even above the provisions of law. Therefore, they will be more satisfied and lead to greater commitment to the business. Next, corporate social responsibility positively affects the reputation of the business with an average impact of 0.173 with a $1 \%$ significance level $\left(P_{-}\right.$value $\left.=0.000\right)$. Businesses that perform social responsibility will create a better reputation because of their responsible behavior. When businesses implement CSR with customers, they will create customer satisfaction that leads to positive word of mouth and create trust for customers. From there, the brand, image, reputation of the business will be improved. Especially with the institutional context in Vietnam, implementing CSR can also attract the confidence and support of the government. In the context of being a country with a socialist institution, the leading birds lead the responsibilities and obligations, exemplary perform activities to ensure the rights of stakeholders such as: Employees, Consumers, especially the environment, are highly concerned, praised and created by the Government and create favorable conditions for production and business activities. Therefore, social responsibility affects government support with a very strong impact coefficient of 0.440 at $1 \%$ significance level $\left(\mathrm{P}_{-}\right.$value $\left.=0.000\right)$.

When considering the impact of intermediaries on financial performance, the commitment of employees, business reputation and government support, Employee commitment has a positive impact on financial performance at an impact level of 0.150 with a $1 \%$ significance level $\left(\mathrm{P}_{-}\right.$value $\left.=0.000\right)$. Reputation has a positive impact on financial performance with an impact level of 0.219 at the $1 \%$ significance level $\left(\mathrm{P}_{-}\right.$value $\left.=0.000\right)$. Finally, government support has a very strong impact on financial performance at the impact level of 0.425 at the $1 \%$ significance level $\left(P_{-}\right.$value $\left.=0.000\right)$.

Summary of test results of research hypotheses is as follows:

Table 5

Path Coefficients (Mean, STDEV, T-Values, P-Values)

\begin{tabular}{|c|c|c|c|c|c|}
\hline & $\begin{array}{c}\text { Original } \\
\text { Sample }(\mathrm{O})\end{array}$ & $\begin{array}{c}\text { Sample } \\
\text { Mean (M) }\end{array}$ & $\begin{array}{c}\text { Standard Deviation } \\
(\text { STDEV) }\end{array}$ & $\begin{array}{l}\text { T Statistics } \\
(|\mathrm{O} / \mathrm{STDEV}|)\end{array}$ & $\begin{array}{c}\mathrm{P} \\
\text { Values }\end{array}$ \\
\hline CSR_Community $\rightarrow$ Corporate social responsibility & 0.202 & 0.204 & 0.014 & 14.263 & 0.000 \\
\hline CSR_Customer $\rightarrow$ Corporate social responsibility & 0.127 & 0.126 & 0.015 & 8.381 & 0.000 \\
\hline CSR_Employee $\rightarrow$ Corporate social responsibility & 0.235 & 0.234 & 0.014 & 17.283 & 0.000 \\
\hline CSR_Enviroment $\rightarrow$ Corporate social responsibility & 0.113 & 0.115 & 0.009 & 12.448 & 0.000 \\
\hline CSR_Investor $\rightarrow$ Corporate social responsibility & 0.171 & 0.170 & 0.012 & 14.087 & 0.000 \\
\hline CSR_Supplier $\rightarrow$ Corporate social responsibility & 0.193 & 0.192 & 0.015 & 12.842 & 0.000 \\
\hline Corporate Reputation $\rightarrow$ Financial Performance & 0.219 & 0.218 & 0.047 & 4.689 & 0.000 \\
\hline Corporate social responsibility $\rightarrow$ Corporate Reputation & 0.173 & 0.177 & 0.049 & 3.506 & 0.000 \\
\hline Corporate social responsibility $\rightarrow$ Employee commitment & 0.187 & 0.191 & 0.049 & 3.819 & 0.000 \\
\hline Corporate social responsibility $\rightarrow$ Government Support & 0.440 & 0.443 & 0.041 & 10.839 & 0.000 \\
\hline Employee commitment $\rightarrow$ Financial Performance & 0.150 & 0.151 & 0.045 & 3.302 & 0.001 \\
\hline Government Support $\rightarrow$ Financial Performance & 0.425 & 0.428 & 0.039 & 10.784 & 0.000 \\
\hline
\end{tabular}

\section{Conclusion}

Textile and apparel industry in recent years has developed strongly and continuously affirmed its leading position in the economy. Along with the trend of deeper and deeper integration, Vietnam is also gradually reaching out to the world when signing new generation FTA agreements such as EVFTA, CPTPP. The implementation of social responsibility is becoming increasingly more urgent than ever to meet world standards. Therefore, businesses need to take measures to improve the implementation of CSR. In order to raise the awareness of CSR implementation for Vietnam's textile and garment export industry, enterprises are recommended to:

Firstly, raise awareness about corporate social responsibility.

Enterprises should propagate and update environmental, community and social issues for the whole enterprise. Make specific requirements on this issue based on requirements and regulations of the Government as well as adjust and publish the relevant laws and regulations. The reality shows that the problem of awareness of CSR of Vietnamese enterprises is uneven. Therefore, enterprises in general and Vietnam's export textile enterprises in particular need to pay more attention and appreciate CSR more.

Secondly, establishing intensive research teams on CSR.

Understanding, dealing with and providing solutions to CSR-related issues needs to be analyzed and evaluated by a professional team before the company can introduce CSR policies, especially for state enterprises. At some large Vietnamese textile and garment export enterprises such as Song Hong or Dap Cau, businesses have long been established and directly invested in this team. 
However, for small and medium enterprises, this is also difficult for them when they do not have enough capacity to implement. Therefore, managers should learn and arrange the work in a "rudimentary" way instead of in depth to suit the costs and capabilities of the business while ensuring the need to implement CSR.

Third, preserve and promote the achievements; promptly find fault, learn experience and change to be accepted.

Each business will have its own advantages and disadvantages, so it should promote the advantages and limit the disadvantages. Learning experiences and making appropriate changes has also become an important recommendation for Vietnam export garment enterprises. The reality shows that because businesses have different perceptions about CSR, there are also different ways to implement CSR, it is extremely important to learn and cultivate everything together not only affects the performance of enterprises but also enhances the position of textile and garment export industry in Vietnam market as well as Vietnam's position in the integration period.

Corporate CSR issues are an important factor leading to sustainable development. Therefore, Vietnamese textile and garment export enterprises should not ignore this issue. In addition, it is necessary to raise awareness and awareness of CSR implementation, opening new directions for the development of export textile enterprises in particular and Vietnam in general.

In addition to enterprise solutions, the state should also have appropriate policies to improve the ability to meet social responsibility for businesses. The team proposed some solutions as follows:

Firstly, perfecting legal documents to enhance the implementation of corporate social responsibility.

In order for businesses to stabilize production and business and achieve the goals of the plan, the government should first have a uniform legal system and consistent with the current situation.

Since 1993, the Law on Environmental Protection, together with other documents related to this issue, has been enacted and implemented nationwide. For employees, the State has also enacted and applied the Labor Code 2012. The Labor Code 2012 and the Law on Environmental Protection play an important position to regulate the behavior of businesses with workers. Therefore, the state needs to have clearer and more comprehensive regulations on the rights and scope from which businesses have a measuring scale to assess their social responsibility performance such as environmental sanitation, emissions into the environment, waste disposal or labor safety, pensions, bonuses, etc. However, the violations are becoming more sophisticated and complicated, so the updating and refunding Further improve the legal framework to force businesses to seriously implement social responsibilities.

In addition, the government needs to establish an appropriate, easily accessible information network so that businesses can keep up to date on the content of new terms to quickly have appropriate strategies.

Secondly, solutions to raise awareness of corporate social responsibility.

Propagating and raising awareness of the role and benefits of social responsibility are necessary to meet the current CSR standards of the world. In particular, consumers play an important role in the policies and directions of the business. The nature of CSR implementation is beneficial for exporting businesses, because European, American consumers usually only use the products of qualified businesses.

Leaders and managers also object that need to be targeted since they are the brain of the business. When there is a proper awareness, businesses will implement CSR voluntarily and positively.

Supplement materials and contents of propaganda through the media, organize training courses, seminars, etc. so that businesses and the community have a correct and complete view of CSR.

Third, enhance the effectiveness of inspection and examination.

Along with raising awareness and improving the legal framework, the Government needs to strengthen the role of relevant agencies to closely monitor corporate social responsibility activities.

Strictly handle cases of intentionally violating regulations on the implementation of social responsibility affecting the interests of the environment and community. Check regularly or even unexpectedly to promptly detect and rectify mistakes. However, the inspection work should also be balanced to avoid affecting the production activities of the business.

Promote the role of the community to denounce, detect cases of violations with relevant authorities or through the media to get the government involved.

Fourthly, research on supporting mechanisms and policies for enterprises. 
In addition to strictly handling violations, the State needs to provide incentives and rewards to businesses that are self-conscious and actively implement CSR such as awards for social responsibility and trademarks green or consider aspects to consider major awards or titles like labor heroes.

Implement supporting activities such as financial resources, clean technology, administrative procedures, etc. to attract businesses to voluntarily perform social responsibilities.

Encourage businesses to build and manage the value chain according to the state's roadmap each year to suit the situation of international economic integration.

Fifth, carry out cooperation activities with international organizations, sign free trade agreements.

In the economic development of the country, especially since Vietnam officially joined the World Trade Organization (WTO), Vietnam's economy is increasingly integrating deeply into the region and the world. The opening of the economy has become an important driving force for economic growth, contributing significantly to maintaining the annual high growth rate of Vietnam's economy. Thus, participating in the process of international economic integration, global supply chains is indispensable to the situation of Vietnam.

Recently, Vietnam has participated in new generation agreements such as EVFTA, CPTPP, etc. According to the provisions of EVFTA, up to $70 \%$ of goods are subject to tax reduction and import tax abolition with $99.7 \%$. These are positive signs for Vietnamese businesses as well as challenges for businesses. Thus, trade agreements are the driving force for Vietnamese enterprises in general and export textile enterprises in particular to perform social responsibilities. So, there is a need for seizing the opportunity, taking advantage of the agreements, boosting exports to new markets. In order to improve the operational efficiency of Vietnamese textile and garment export enterprises during the integration period, the Vietnamese Government needs:

Strengthen deeper cooperation with each country to achieve special incentives suitable to the common purpose without harming the interests and development opportunities of the two sides.

Continue dialogue between parties such as associations such as the Association of Southeast Asian Nations (ASEAN), AsiaPacific Economic Cooperation (APEC), etc. to affirm the contribution. At the same time, they also propose change policies with appropriate roadmap to create favorable conditions for cooperation and development.

Sixthly, strengthening education for university students about knowledge and awareness about CSR

Educating university students on CSR will be a long-term, visionary strategy of the government. Because students are the future owners of the country, maybe one of them will be business owners in the future. So, if students are still aware of CSR right from the lecture hall, this will be an important foundation in the future when owning their own business.

\section{References}

Ali, I., Rehman, K.U., Yilmaz, A.K., Nazir, S., \& Ali, J.F. (2010). Effects of corporate social responsibility on consumer retention in cellular industry of Pakistan. African Journal of Business Management., 4(4), 475-485.

Agyemang, K., \& Ansong, A. (2017). Corporate social responsibility and firm performance of Ghanaian SMEs: The role of stakeholder engagement. Cogent Business \& Management, 4, 1-18, DOI: 10.1080/23311975.2017.1333704

Brik, A. B., Rettab, B., \& Mellahi, K. (2010). Market orientation, corporate social responsibility, and business performance. Journal of Business Ethics, 99(3), 307-324. DOI: 10.1007/s10551-010-0658-z.

Brown, T., \& Dacin, P. (1997). The company and the product: Corporate associations and consumer product responses. Journal of Marketing, 61(1), 68-84. doi:10.2307/1252190

Carroll, A. (1979). A three-dimensional conceptual model of corporate performance. The Academy of Management Review, 4(4), 497-505.

Carroll, A. B. (2015). Corporate social responsibility: The centerpiece of competing and complimentary frameworks. Organizational Dynamics, 44, 87-96.

Chetty, S., Naidoo, R., \& Seetharam, Y. (2015). The impact of corporate social responsibility on firms' financial performance in South Africa. Contemporary Economics, 9(2), 193-214.

Clarkson, M. B. E. (1995). A stakeholder framework for analyzing and evaluating corporate social performance. Academy of Management Review, 20, 92-117.

Davis, G., \& Searcy, C. (2010). A review of Canadian corporate sustainable development reports. Journal of Global Responsibility, 1(2), 316-329. https://doi.org/10.1108/20412561011079425 
Firth, M. (1979). The impact to size, stock market listing, and auditors on voluntary disclosure in corporate annual reports. Journal of Accounting and Business Research, 9(1), 273-280. https://doi.org/10.1080/00014788.1979.9729168

Friedman, A. L., \& Miles, S. (2002). Developing stakeholder theory. Journal of Management Studies, 39(1), 1-21. https://doi.org/10.1111/1467-6486.00280

Gillis, T. \& Spring, N. (2001). Doing good is good for business. Communication World, 18(6), $23-38$.

Hair, J.F., Ringle, C.M., \& Sarstedt, M. (2011). PLS-SEM: in deed a silver bullet. Journal of Marketing Theory and Practice, $19(2), 139-151$.

Hair, J.F., Hult, G.T.M., Ringle, C., \& Sarstedt, M. (2013). A Primer on Partial Least Squares Structural Equation Modeling (PLS-SEM), Sage Publications Ltd, London.

Hair, J.F., Henseler, J., Dijkstra, T., Sarstedt, M., Ringle, C., Diamantopoulos, A., Straub, D., Ketchen, D., GTM, H., \& Calantone, R. (2014). Common beliefs and reality about partial least squares: comments on Rönkkö and Evermann, Organizational Research Methods, 17(2), 182-209.

Hair, J. F., Hult, G. T. M., Ringle, C. M., \& Sarstedt, M. (2017). A Primer on Partial Least Squares Structural Equation Modeling (PLS-SEM), $2^{\text {nd }}$ Ed., Sage: Thousand Oaks.

Hasan, I., Kobeissi, N., \& Wang, H. (2018). Corporate social responsibility and firm financial performance: The mediating role of productivity. Journal of Business Ethics, 149, $671-688$.

Henseler, J., Ringle, C.M., \& Sarstedt, M. (2015). A new criterion for assessing discriminant validity in variance-based structural equation modeling. Journal of the Academy of Marketing Science, 43(1), 115-135.

Henseler, J., Ringle, C.M., \& Sinkovics, R.R. (2009). The use of partial least squares path modeling in international marketing, in Sinkovics, R.R. and Ghauri, P.N. (Eds), New Challenges to International Marketing, Emerald Group Publishing Limited.

Holme, R., \& Watts, P. (2000). Corporate Social Responsibility: Making Good Business Sense. World Business Council for Sustainable Development: Geneva.

Jones, T. M. (1980). Corporate social responsibility revisited, redefined. California Management Review, 22(3), 5967. https://doi.org/10.2307/41164877

Le, T. T., Nguyen, T. A., Phan, T. T. H., Tran, M. D., Phung, X. T., Tran, T. T., \& Giao, K. N. (2019). Impact of corporate social responsibility on supply chain management and financial performance in Vietnamese garment and textile firms. Uncertain Supply Chain Management, 7(3), 679-690.

Mishra, S., \& Suar, D. (2010). Does corporate social responsibility influence firm performance of Indian companies? Journal of Business Ethics 95(4), 571-601. DOI 10.1007/s10551-010-0441-1.

McWilliams, A., \& Siegel., D. (2001). Corporate social responsibility and financial performance: correlation or misspecification? Strategic Management Journal, 21(5), 603-609

Nikolova, V., \& Arsić, S. (2017). The stakeholder approach in corporate social responsibility. Engineering Management, $3(1), 24-35$.

Obeidat, B. Y., Al-Sarayrah, S., Tarhini, A., Al-Dmour, R. H., Al-Salti, Z., \& Sweis, R. (2016). Cultural Influence on Strategic Human Resource Management Practices: A Jordanian case study. International Business Research, 9(10), 94-114. https://doi.org/10.5539/ibr.v9n10p94

Phan, T. T. H., Doan, X. T., \& Nguyen T. T. T. (2020). The impact of supply chain practices on performance through supply chain integration in textile and garment industry of Vietnam. Uncertain Supply Chain Management, 8(1), $175-186$.

Phan, T. T. H., \& Nguyen, T. T. L. (2018). Research on awareness and status of corporate social responsibility in Vietnamese textile enterprises. Journal of Economics and Development, 254(8/2018), 106-112.

Rettab, B., Brik, A. B., \& Mellahi, K. (2009). A study of management perceptions of the impact of corporate social responsibility on organisational performance in emerging economies: The case of Dubai. Journal of Business Ethics, 89, 371-390. DOI 10.1007/s10551-008-0005-9

Roberts, R. W. (1992). Determinants of corporate social responsibility disclosure: An application of stakeholder theory. Accounting, Organizations and Society, 17(6), 595-612. https://doi.org/10.1016/0361-3682(92)90015-K

Saeidi, S. P., Sofian, S., Saeidi, P., Saeidi, S. P., \& Saaeidi, S. A. (2015). How does corporate social responsibility contribute to firm financial performance? The mediating role of competitive advantage, reputation, and customer satisfaction. Journal of Business Research, 68(2), 341-350. doi:https://doi.org/10.1016/j.jbusres.2014.06.024

Santos, \& Brito. (2012). Toward a subjective measurement model for firm performance. Brazilian Administration Review, 9 , 95-117.

Smith, W. J., Wokutch, R. E., Harrington, K. V., \& Dennis, B. S. (2001). An examination of the influence of diversity and stakeholder role on corporate social orientation. Business and Society, 40(3), 266-94.

Tran, H., Bui, V., Phan, T., Dau, X., Tran, M., \& Do, D. (2019). The impact of corporate social responsibility and risk management on financial performance: The case of Vietnamese textile firms. Management Science Letters, 9(7), 1029-1036.

Wood, D. J. (1991). Corporate social responsibility revisited. Academy of Management Review, 16, 691-718.

Zenisek, T. (1979). Corporate Social Responsibility: A Conceptualization Based on Organizational Literature. The Academy of Management Review, 4(3), 359-368. 


\section{Appendix}

A. Corporate social responsibility

1. Community responsibilities

- Give money to charities in the communities where we operate

- Help improve the quality of life in the communities where we operate

- $\quad$ Financially support community activities (arts, culture, sports)

- Financially support education in the communities where we operate

2. Environmental responsibilities

- Incorporate environmental performance objectives in organisational plans

- Voluntarily exceed government environmental regulations

- $\quad$ Financially support environmental initiatives

- Measure the organisation's environmental performance

3. Employee responsibilities

- Treat all employees fairly and respectfully, regardless of gender or ethnic background

- $\quad$ Provide all employees with salaries that properly and fairly reward them for their work

- Support all employees who want to pursue further education

- Help all employees coordinate their private and professional lives

- Incorporate the interests of all employees into business decisions

4. Investor responsibilities

- Incorporate the interests of all our investors into business decisions

- $\quad$ Provide all investors with a competitive return on investment

- $\quad$ Seek the input of all our investors regarding strategic decisions

- Meet the needs and requests of all our investors

5. Customer responsibilities

- $\quad$ Provide all customers with very high quality service

- $\quad$ Provide all customers with the information needed to make sound purchasing decisions

- Satisfy the complaints of all customers about the company's products or services

- Adapt products or services to enhance the level of customer satisfaction

6. Supplier responsibilities

- $\quad$ Provide all suppliers of products and services with a commitment to a future relationship

- Offer all suppliers of products and services some price guarantees for the future

- Incorporate the interests of all suppliers of products and services into business decisions

- Involve all suppliers in new product or service development 
Inform all suppliers of products and services about organisational changes affecting purchasing decisions

B. Financial performance

Relative to our largest competitor, during the last year we

- $\quad$ Had a larger market share

- Were larger in size

Regarding our overall performance, during the last year we

- $\quad$ Performed poorly relative to competitors

Relative to our largest competitor, during the last year we

- $\quad$ Our return on investment has been sub- stantially better

- $\quad$ Our return on assets has been substantially better

- $\quad$ Our sales growth has been substantially better

- $\quad$ Our profit growth has been substantially better

C. Corporate reputation

- In general, our organisation has a good reputation

- We are widely acknowledged as a trust- worthy organisation

- This organisation is known to sell high quality products and services

D. Employee commitment

- $\quad$ Our employees often go above and beyond their regular responsibilities to ensure the organisation's well-being

- $\quad$ The bonds between this organisation and its employees are very strong

- $\quad$ Our people are very committed to this organization

E. Government support

- The government gives supports for transportation

- The government gives supports for staff employment

- The government gives supports for administration and legal services

- CSR facilitates the relationship between the firm and the government

- The government gives supports whenever the firm needs

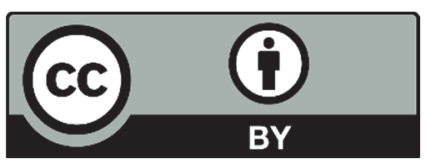

(C) 2020 by the authors; licensee Growing Science, Canada. This is an open access article distributed under the terms and conditions of the Creative Commons Attribution (CC-BY) license (http://creativecommons.org/licenses/by/4.0/). 